Short Communication

\title{
The Effect of Salinity on Native Proteolytic Activity in Soil
}

\author{
Ladislav Holik*, Valerie Vranová, Klement Rejšek \\ Mendel University in Brno, Faculty of Forestry and Wood Technology, Department of Geology and Soil Science, \\ Zemědělská 3, 61300 Brno, Czech Republic
}

Received: 20 March 2017

Accepted: 3 May 2017

\begin{abstract}
Salinization of soil has a negative impact on the activity of microorganisms and thus leads to disturbances in the cycling of nutrients in the soil environment. Our goal was to determine what amount of salt has some measurable negative effect on enzymatic activity of soils, namely on native proteases. Inhibition of proteases was detected at as little as $0.5 \mathrm{mg}$ of chloride salts in an organomineral horizon from an oak stand, but in most cases, some inhibitory effect appeared from 1-2 mg of salt added to the soil. Although the stimulatory effects of salt were also observed, in those cases it probably was not associated with activity of the microbial community. Our results indicate the levels from which the activity of microorganisms will probably decrease and organic matter decomposition will be slowed.
\end{abstract}

Keywords: enzymes, forest soil, salinity, soil environment, soil protease

\section{Introduction}

The application of road salt is a common practice in winter road maintenance with the objective of ensuring safe driving conditions; the most widely used salt is $\mathrm{NaCl}$ [1]. However, extensive application of road salt presents a serious problem for the environment [2-3]. The applied salt enters the soil environment in the form of direct runoff, in splashing water, or as aerosol deposition [4]. Soil salinization is a major factor leading to degradation [56] and decrease of soil fertility [7]. Biological activity often concentrates in the upper few centimetres of soil [8], and changes in this layer may strongly affect its biological properties. From the aspect of ecological function, soil biological activity is essential and its reduction has a significant impact on decomposition of organic matter in soil [9-10].

*e-mail: ladislav.holik@mendelu.cz
Salinization of soil causes alkaline reaction, high osmotic pressure, and toxic effects of easily soluble salts (sodium and magnesium chlorides, nitrates, sulphates, and carbonates); besides, it also negatively affects hydro-physical properties of soils. The influence of sodium in the presence of chlorides dramatically restricts uptake of nutrients from the salinized soil - especially of nitrogen, phosphorus, and magnesium. This leads to unbalanced mineral nutrition or even starvation of plants, and also to a lower chance of their survival upon exposure to extreme natural and anthropogenic influences [11].

In our work we investigated the impact of salts on native protease activity of soils. Natrium chloride $(\mathrm{NaCl})$ was selected for the experiments as it constitutes $96-98 \%$ of road salt (the rest is anticaking agents). One chloride salt $(\mathrm{KCl})$ and one sulphate salt $\left(\mathrm{K}_{2} \mathrm{SO}_{4}\right)$ were also tested. The salts were applied into soil in graded amounts in order to find out how much salt (in $\mathrm{mg}$ ) in the soil environment leads to inhibition of native proteases. The presumption 
of the negative effect of salts was based on the work of Saviozziet et al. [9].

\section{Experimental}

\section{Study Area and Soil Sampling}

The research of protease activity was carried out in the stands of the Training Forest Enterprise Masaryk Forest Krrtiny (TFE Krrtiny), with altitudes between 210-575 m a.s.1., mean annual temperature of $7.5^{\circ} \mathrm{C}$, and mean annual precipitation of $610 \mathrm{~mm}$. Four experimental plots were selected, three of them with a broadleaved stand (two beech stands and one oak stand) and one with a coniferous stand (spruce).

The first locality was Mácha's memorial (N49 $19^{\prime} 24^{\prime \prime}$, E16 $\left.40^{\prime} 19^{\prime \prime}\right)$ with a stand of European beech (Fagus sylvatica L., aged 70 years) in rendzic Leptosol soil. Samples were collected from organic (Oe), organomineral (Ahk), and mineral horizon (Bwk). The second locality was Útěchov (N4918'1'", E16 $\left.{ }^{\circ} 37^{\prime} 31^{\prime \prime}\right)$ with a stand of Pedunculate oak (Quercus robur L., aged 35 years) in haplic Cambisol soil. Samples were collected from organomineral (Ah) horizon and mineral horizon $(\mathrm{Bw})$. At the third locality, Jedovnice, two stands were investigated: a beech stand (Fagus sylvatica L., aged 90 years, N49 $19^{\prime} 19^{\prime \prime}$, E16 $\left.47^{\prime} 48^{\prime \prime}\right)$ and a spruce stand (Picea abies /L./ Karst., aged 100 years, N4919'21"', E16 $\left.47^{\prime} 38^{\prime \prime}\right)$. In both stands, the soil type is haplic Cambisol; samples were collected from organic (Oe), organomineral (Ah) and mineral horizon (Bw).

Sampling was performed in the middle of the vegetation season (end of June), when the highest biological activity is to be expected. Composite samples of three samplings from the individual horizons were sieved through a 2-mm sieve. Selected physical and chemical characteristics of the tested soils are shown in Table 1. The plots were chosen with the aim to reflect the heterogeneity of the soil environment, both with regard to the soil type and the tree species composition; the represented soil types and stands are typical for the territory of the Czech Republic.

\section{Determining Soil Proteolytic Activity}

Native protease activity of soils was determined according to Rejsek et al. [12]. $2 \mathrm{~g}$ of soil were mixed with $100 \mu \mathrm{l}$ demineralized $\mathrm{H}_{2} \mathrm{O}$ with dissolved salt at concentrations of $0.5,1,2$, and $4 \mathrm{mg}$ per gram of dry soil. The tested salts were natrium chloride $(\mathrm{NaCl})$, potassium chloride $(\mathrm{KCl})$, and potassium sulfate $\left(\mathrm{K}_{2} \mathrm{SO}_{4}\right)$.

\section{Statistical Analysis}

Statistical evaluation of the values of proteolytic activity detected in the individual samples was performed by one-way ANOVA and Fischer's LSD test (multiple comparison) with the use of the Statistica 12.0 software.

\section{Results and Discussion}

In beech stands, native protease was the most sensitive to potassium sulfate as inhibition of protease activity appeared already at the $0.5 \mathrm{mg}$ and $1 \mathrm{mg}$ of salt applied (Table 2); response to chloride salts $(\mathrm{NaCl}, \mathrm{KCl})$ was generally lower and inhibition occurred at 2 or $4 \mathrm{mg}$ of salt (Table 2). Stimulation of native proteases was also observed in one measurement, after the application of $\mathrm{NaCl}$ and $\mathrm{K}_{2} \mathrm{SO}_{4}$ to samples from the beech stand in haplic Cambisol soil (Table 2). The influence of natrium chloride was not statistically significant $(\mathrm{P}<0.05)$ in organic and organomineral horizons on rendzic Leptosol (Table 2). In the oak stand, inhibitory response of native protease to the presence of salts in the organomineral horizon appeared at as little as $0.5 \mathrm{mg}$. In the mineral horizon, inhibition occurred with 1

Table 1. Selected physical and chemical properties of the tested soils.

\begin{tabular}{|c|c|c|c|c|c|c|c|c|}
\hline Plot & $\begin{array}{c}\mathrm{C}_{\mathrm{t}} \\
(\%)\end{array}$ & $\begin{array}{c}\mathrm{N}_{\mathrm{t}} \\
(\%)\end{array}$ & $\mathrm{C} / \mathrm{N}$ & $\begin{array}{c}\mathrm{pH} \\
\mathrm{H}_{2} \mathrm{O}\end{array}$ & $\begin{array}{c}\mathrm{pH} \\
1 \mathrm{M} \mathrm{KCl}\end{array}$ & $\begin{array}{c}\text { Clay } \\
(\%)\end{array}$ & $\begin{array}{c}\text { Silt } \\
(\%)\end{array}$ & $\begin{array}{c}\text { Sand } \\
(\%)\end{array}$ \\
\hline Beech, Oe horizon (rendzic Leptosol) & 19.68 & 1.60 & 12.3 & 7.00 & 6.59 & - & - & - \\
\hline Beech, Ahk horizon (rendzic Leptosol) & 13.70 & 1.07 & 12.8 & 7.18 & 6.91 & 12.47 & 65.04 & 22.49 \\
\hline Beech, Bwk horizon (rendzic Leptosol) & 2.45 & 0.19 & 12.8 & 6.80 & 6.44 & 23.20 & 60.30 & 16.50 \\
\hline Beech, Oe horizon (Cambisol) & 11.93 & 0.66 & 18.1 & 4.29 & 3.98 & - & - & - \\
\hline Beech, Ah horizon (Cambisol) & 5.98 & 0.42 & 14.2 & 4.79 & 4.09 & 6.40 & 48.80 & 44.70 \\
\hline Beech, Bw horizon (Cambisol) & 3.16 & 0.16 & 19.8 & 4.54 & 3.98 & 18.7 & 56.60 & 24.70 \\
\hline Oak, Ah horizon (Cambisol) & 8.54 & 0.59 & 14.5 & 5.12 & 4.46 & 6.81 & 50.03 & 43.15 \\
\hline Oak, Bw horizon (Cambisol) & 1.22 & 0.08 & 15.3 & 4.31 & 3.42 & 26.50 & 36.00 & 37.40 \\
\hline Spruce, Oe horizon (Cambisol) & 26.76 & 1.34 & 20.0 & 4.07 & 3.35 & - & - & - \\
\hline Spruce, Ah horizon (Cambisol) & 8.16 & 0.46 & 17.7 & 4.22 & 3.26 & 10.40 & 50.90 & 38.60 \\
\hline Spruce, Bw horizon (Cambisol) & 1.22 & 0.08 & 15.3 & 4.50 & 3.60 & 21.60 & 52.50 & 25.80 \\
\hline
\end{tabular}


Table 2. Protease activity after the addition of salts at $0,0.5,1,2$, and $4 \mathrm{mg} \mathrm{g}^{-1}$ dry soil. Results are reported as the average value of the amount of produced $\mu \mathrm{g}$ L-tyrosine $\mathrm{h}^{-1} \mathrm{~g}^{-1}$ dry soil; values marked with * are statistically significant $(\mathrm{P}<0.05, \mathrm{n}=3)$. Results for Standard error (SE \pm ) of Fisher's LSD tests.

\begin{tabular}{|c|c|c|c|c|c|c|}
\hline Plot & 0 & 0.5 & 1 & 2 & 4 & $\mathrm{SE} \pm$ \\
\hline \multicolumn{7}{|c|}{ Beech, Oe horizon (rendzic Leptosol) } \\
\hline $\mathrm{NaCl}$ & 557.67 & 557.67 & 561.43 & 563.13 & 558.02 & 5.74 \\
\hline $\mathrm{KCl}$ & 557.67 & 569.96 & 560.06 & $540.95^{*}$ & $528.32 *$ & 7.10 \\
\hline $\mathrm{K}_{2} \mathrm{SO}_{4}$ & 557.67 & $546.07 *$ & $533.78 *$ & $524.23 *$ & $528.66^{*}$ & 2.85 \\
\hline \multicolumn{7}{|c|}{ Beech, Ahk horizon (rendzic Leptosol) } \\
\hline $\mathrm{NaCl}$ & 378.11 & 370.49 & 376.84 & 382.93 & 384.20 & 5.81 \\
\hline $\mathrm{KCl}$ & 378.11 & $400.45^{*}$ & 379.63 & 373.85 & 385.72 & 4.11 \\
\hline $\mathrm{K}_{2} \mathrm{SO}_{4}$ & 378.11 & $366.42 *$ & $366.96^{*}$ & $362.11 *$ & $358.55^{*}$ & 4.97 \\
\hline \multicolumn{7}{|c|}{ Beech, Bwk horizon (rendzic Leptosol) } \\
\hline $\mathrm{NaCl}$ & 82.27 & 77.18 & $71.03 *$ & $68.06^{*}$ & $68.27 *$ & 3.38 \\
\hline $\mathrm{KCl}$ & 82.27 & 74.50 & 74.00 & $67.43^{*}$ & $63.40^{*}$ & 4.89 \\
\hline $\mathrm{K}_{2} \mathrm{SO}_{4}$ & 82.27 & 76.12 & $72.09^{*}$ & $71.24 *$ & $59.79 *$ & 2.99 \\
\hline \multicolumn{7}{|c|}{ Beech, Oe horizon (Cambisol) } \\
\hline $\mathrm{NaCl}$ & 109.93 & 112.57 & $85.75^{*}$ & $58.48^{*}$ & $42.65^{*}$ & 6.19 \\
\hline $\mathrm{KCl}$ & 109.93 & $138.08^{*}$ & $131.48^{*}$ & 108.61 & $97.62 *$ & 4.15 \\
\hline $\mathrm{K}_{2} \mathrm{SO}_{4}$ & 109.93 & $124.45^{*}$ & $121.37 *$ & 106.42 & $100.70 *$ & 2.73 \\
\hline \multicolumn{7}{|c|}{ Beech, Ah horizon (Cambisol) } \\
\hline $\mathrm{NaCl}$ & 73.42 & $84.58 *$ & 75.93 & 67.56 & $60.58 *$ & 2.72 \\
\hline $\mathrm{KCl}$ & 73.42 & $84.86^{*}$ & 67.28 & 66.16 & $55.55^{*}$ & 3.87 \\
\hline $\mathrm{K}_{2} \mathrm{SO}_{4}$ & 73.42 & 74.53 & $65.32 *$ & $63.37^{*}$ & $61.97 *$ & 2.74 \\
\hline \multicolumn{7}{|c|}{ Beech, Bw horizon (Cambisol) } \\
\hline $\mathrm{NaCl}$ & 18.76 & 17.98 & $15.44 *$ & 16.02 & $12.70^{*}$ & 1.25 \\
\hline $\mathrm{KCl}$ & 18.76 & $11.33^{*}$ & $13.29 *$ & $11.14 *$ & $8.79 *$ & 1.52 \\
\hline $\mathrm{K}_{2} \mathrm{SO}_{4}$ & 18.76 & $11.33^{*}$ & $13.29 *$ & $12.11 *$ & $8.99 *$ & 1.69 \\
\hline \multicolumn{7}{|c|}{ Oak, Ah horizon (Cambisol) } \\
\hline $\mathrm{NaCl}$ & 120.54 & $113.11^{*}$ & $113.91 *$ & $112.21^{*}$ & $109.73 *$ & 2.61 \\
\hline $\mathrm{KCl}$ & 120.54 & $112.66^{*}$ & $113.79 *$ & $112.43^{*}$ & $114.69 *$ & 2.10 \\
\hline $\mathrm{K}_{2} \mathrm{SO}_{4}$ & 120.54 & 118.70 & $111.76^{*}$ & $112.21 *$ & $107.03 *$ & 2.82 \\
\hline \multicolumn{7}{|c|}{ Oak, Bw horizon (Cambisol) } \\
\hline $\mathrm{NaCl}$ & 11.18 & 8.52 & $6.74 *$ & $5.50 *$ & $5.50 *$ & 1.88 \\
\hline $\mathrm{KCl}$ & 11.18 & 10.12 & 10.83 & 10.47 & 11.36 & 0.99 \\
\hline $\mathrm{K}_{2} \mathrm{SO}_{4}$ & 11.18 & 10.12 & 10.29 & 10.29 & $7.27^{*}$ & 0.84 \\
\hline \multicolumn{7}{|c|}{ Spruce, Oe horizon (Cambisol) } \\
\hline $\mathrm{NaCl}$ & 93.54 & 86.19 & 84.96 & $79.24 *$ & $80.88 *$ & 4.61 \\
\hline $\mathrm{KCl}$ & 93.54 & $120.50^{*}$ & 89.05 & $71.07 *$ & $56.78^{*}$ & 4.50 \\
\hline $\mathrm{K}_{2} \mathrm{SO}_{4}$ & 93.54 & $105.39 *$ & $81.29 *$ & $74.34 *$ & $47.38^{*}$ & 5.30 \\
\hline
\end{tabular}


Table 2. Continued.

\begin{tabular}{|c|c|c|c|c|c|c|}
\hline \multicolumn{7}{|c|}{ Spruce, Ah horizon (Cambisol) } \\
\hline $\mathrm{NaCl}$ & 62.68 & $36.85^{*}$ & $36.23 *$ & $31.02 *$ & $30.61 *$ & 3.44 \\
\hline $\mathrm{KCl}$ & 62.68 & $77.05^{*}$ & $71.22 *$ & $78.09 *$ & $83.29 *$ & 2.80 \\
\hline $\mathrm{K}_{2} \mathrm{SO}_{4}$ & 62.68 & $33.31^{*}$ & $27.48^{*}$ & $21.86^{*}$ & $20.82 *$ & 2.80 \\
\hline \multicolumn{7}{|c|}{ Spruce, Bw horizon (Cambisol) } \\
\hline $\mathrm{NaCl}$ & 21.23 & 20.63 & 22.83 & 20.63 & $17.42^{*}$ & 1.50 \\
\hline $\mathrm{KCl}$ & 21.23 & 18.42 & $13.42 *$ & $9.81 *$ & $7.61 *$ & 1.79 \\
\hline $\mathrm{K}_{2} \mathrm{SO}_{4}$ & 21.23 & 22.63 & 19.83 & $14.82 *$ & $15.82 *$ & 1.74 \\
\hline
\end{tabular}

$\mathrm{mg} \mathrm{NaCl}$ and $4 \mathrm{mg} \mathrm{K}_{2} \mathrm{SO}_{4}$. A statistically significant effect $(\mathrm{P}<0.05)$ was not observed in $\mathrm{KCl}$.

In spruce stand, salts inhibited native protease activity from the amount of $0.5 \mathrm{mg}$ in the organomineral horizon, while in the organic and mineral horizon it was at 1-2 $\mathrm{mg}$ of salt (Table 2). Similarly to the beech stand, $0.5 \mathrm{mg}$ of salt had a stimulatory effect on the native proteolytic activity in the organic horizon; higher amounts of salt lead to inhibition. An exception from this was found in the organomineral horizon after the addition of $\mathrm{KCl}$, in which case stimulation of proteases was observed in all amounts of salt tested.

An excessive amount of salt has a negative impact on physical and chemical properties of soil [4]. In saline soils, microorganisms suffer from osmotic stress [14], which affects mineralization of carbon and nitrogen as well as enzymatic activity, which is crucial for the decomposition of organic matter [15]. Our objective was to find out from what amount (mg) salts induce inhibition of native soil proteases. Generally speaking, the level from which inhibition appears is rather varied, both from the aspect of enzymatic response to individual salts as such, and in comparison of different sites and their soil horizons. Besides proteases, there are other enzymes sensitive to the presence of salts in soil, for example ureases and catalases [16]. Many authors, such as Saviozzi et al. [9, 17-18], report that salts reduce the activity of enzymes. Inhibition was detected in ureases or dehydrogenases, while amylases and phosphatases did not correlate with increasing salinity and catalases were actually slightly stimulated [9, 19]. Zheng et al. [20] observed a slight stimulation of catalases as well, although only in combination with the addition of lead. In other enzymes (ureases and invertases) they also found inhibited activity. Similar results were reported by Wei et al. [21] in nitrite reductases and nitrate reductases which are, just like proteases, directly linked to nitrogen mineralization. Inhibition may be partially caused by the tendency of salts to reduce solubility and denaturation of enzymes by disturbing their tertiary structure, which is necessary for enzymatic activity [20]. Salinity also reduces the production, solubility, and denaturation of proteins and thus further reduces enzymatic activity [19].

However, the stimulatory effect of salts on proteolytic activity has been observed as well. It was found that increased salinity may also support mineralization of nitrogen $\left(\mathrm{NH}_{4}^{+}-\mathrm{N}\right.$ a $\left.\mathrm{NO}_{3}{ }^{-} \mathrm{N}\right)$ in soils [22-23]. Pathak and Rao [13] report that nitrogen mineralization may continue despite the microbial activity being supressed by the presence of salts. This is possible thanks to the enzymes that are still present in soil, but their activity has not yet been affected by high salinity and alkalinity of the soil environment. It is probable that the same response appeared in our experiment, i.e., the activity of enzymes was not affected by alkalinity/salinity of the soil environment. This presumption is based on the fact that sorption capacity of the organic and organomineral horizons in a forest environment is high and the presence of enzymes bound by sorption is therefore to be expected.

\section{Conclusions}

In the presented study we aimed to find out what amount of salt is sufficient to induce inhibition of native proteases in soils of forest stands. In our experiments, inhibition appeared at as little as 0.5 to $1 \mathrm{mg}$ of salt depending on the soil horizon. These results may help to determine the level of salinity from which the microbial community activity will probably be disturbed, with consequences for decomposition of organic matter in soil.

\section{Acknowledgements}

This output was based on the project IGA 13/2013. We thank the internal grant agency of Mendel University in Brno (MENDELU) for their support in its implementation.

\section{References}

1. GUESDON G., DE SANTIAGO-MARTIN A., GALVEZCLOUTIER R. Phytodesalinization potential of Typha angustifolia, Juncus maritimus, and Eleocharis palustris for removal of de-icing salts from runoff water. Environ. Sci. Pollut. Res. 23, 19634, 2016.

2. KIM S.Y., KORETSKY C. Effects of road salt deicers on sediment biogeochemistry. Biogeochemistry 112, 343, 2013. 
3. LI F., ZHANG Y., FAN Z., OH K. Accumulation of De-icing Salts and Its Short-Term Effect on Metal Mobility in Urban Roadside Soils. Bull. Environ. Contam. Toxicol. 94, 525, 2015.

4. GREEN S.M., MACHIN R., CRESSER M.S. Effect of long-term changes in soil chemistry induced by roadsalt applications on N-transformations in roadside soils. Environ. Poll. 152, 20, 2008.

5. VAN ANTWERPEN R., MEYER J.H. Soil degradation under sugarcane cultivation in northern Kwa Zulu-Natal. Proc. S. Afr. Sug. Technol. Assoc. 70, 29, 1996.

6. HAYNES R.J., HAMILTON C.S. Effects of sugarcane production on soil quality: A synthesis of world literature. Proc. S. Afr. Sug. Technol. Assoc. 73, 45, 1999.

7. FERNÁNDEZ-LUQUEÑO F., CABRERA-LÁZARO G., CORLAY-CHEE L., LÓPEZ-VALDEZ F., DENDOOVEN L. Dissipation of Phenanthrene and Anthracene from Soil with Increasing Salt Content Amended with Wastewater Sludge. Pol. J. Environ. Stud. 26 (1), 29, 2017.

8. MURPHY D.V., SPARLING G.P., FILLERY I.R.P. Stratification of microbial biomass $\mathrm{C}$ and $\mathrm{N}$ and gross $\mathrm{N}$ mineralization with soil depth in two contrasting western Australian agricultural soils. Austral. J. Soil Res. 36, 45, 1998.

9. SAVIOZZI A., CARDELLI R., DI PUCCIO R. Impact of Salinity on Soil Biological Activities: A Laboratory Experiment. Comm. Soil Sci. Plant. Anal. 42, 358, 2011.

10. ELMAJDOUB B., MARSCHNER P. Responses of soil microbial activity and biomass to salinity after repeated additions of plant residues. Pedosphere 25, 177, 2015.

11. ARTAMONOVA V.S., DITS L.Y., ELIZAROVA T.N., LYUTYKH I.V.Technogenic salinization of soils and their microbiological characterization. Contem. Probl. Ecol. 3, 323, 2010.

12. REJSEK K., FORMANEK P., PAVELKA M. Estimation of protease activity in soil satlow temperatures by casein amendment and with substitution of buffer by demineralized water. Amino Acids 35, 411, 2008.

13. PATHAK H., RAO D.L.N. Carbon and nitrogen mineralization from added organic matter in saline and alkali soils. Soil Biol. Biochem. 30, 695, 1998.
14. YAN N., MARSCHNER P., CAO W., ZUO C., QIN $\mathrm{W}$. Influence of salinity and water content on soil microorganisms. Int. Soil and Water Cons. Res. 3 (4), 316, 2015.

15. DENDOOVEN L., ALCÁNTARA-HERNÁNDEZ R.J., VALENZUELA-ENCINAS C., LUNA-GUIDO M., PEREZ-GUEVARA F., MARSCH R. Dynamics of carbon and nitrogen in an extreme alkaline saline soil: a review. Soil Biol. Biochem. 42 (6), 865, 2010.

16. GUANGMING L., XUECHEN Z., XIUPING W., HONGBO S., JINGSONG Y., XIANGPING W. Soil enzymes as indicators of saline soil fertility under various soil amendments. Agric. Ecosys. Environ. 237, 274, 2017.

17. PAN C., LIU C., ZHAO H., WANG Y. Changes of soil physico-chemical properties and enzyme activities in relation to grassland salinization. Eur. J. Soil Biol. 55, 13, 2013.

18. SINGH K. Microbial and enzyme activities of saline and sodic soils. Land Degr. Develop. 27 (3), 706, 2016.

19. RATH K.M., ROUSK J. Salt effects on the soil microbial decomposer community and their role in organic carbon cycling: a review. Soil Biol. Biochem. 81, 108, 2015.

20. ZHENG L., ZHANG M., XIAO R., CHEN J., YU F. Impact of salinity and $\mathrm{Pb}$ on enzyme activities of a saline soil from the Yellow River delta: A microcosm study. Phys. and Chem. Of the Earth 97, 77, 2017.

21. WEI M.I.N., GUO H.J., ZHANG W., ZHOU G.W., JUN Y.E., HOU Z.A. Irrigation water salinity and $\mathrm{N}$ fertilization: Effects on ammonia oxidizer abundance, enzyme activity and cotton growth in a drip irrigated cotton field. J. Integr. Agric. 15 (5), 1121, 2016.

22. GAO H., BAI J., HE X., ZHAO Q., LU Q., WANG J. High temperature and salinity enhance soil nitrogen mineralization in a tidal freshwater marsh. PloS one 9 (4), 95011, 2014.

23. JIA J., BAI J., GAO H., WEN X., ZHANG G., CUI B., LIU $X$. In situ soil net nitrogen mineralization in coastal salt marshes (Suaeda salsa) with different flooding periods in a Chinese estuary. Ecol. Indic. 73, 559, 2017. 